Available online on 15.11.2017 at http://ujpr.org
Universal Journal of Pharmaceutical Research
An International Peer Reviewed Journal
Open access to Pharmaceutical research

\title{
RISK FACTORS OF PERIODONTAL DISEASES AMONG YEMENI YOUNG DENTAL PATIENTS
}

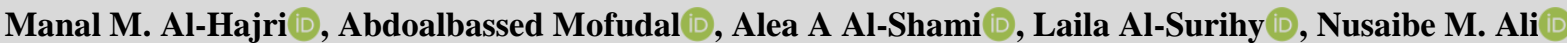
Oral Medicine, Oral Diagnosis and Periodontology Department, Sanaa University, Yemen.

\section{ABSTRACT}

Periodontal diseases are chronic infectious diseases that lead to the inflammation of specialized tissues that surround and support the teeth. Many risk factors and risk indicators, associated with increased risk of periodontal disease, have been identified. Gender, age, education, tooth brushing habit, smoking, khat chewing and Shamaa use were associated with periodontal status in Yemen. Accordingly, the aim of our study is to assess the prevalence and related risk factors for periodontal diseases among Yemeni young dental patients in the faculty of dentistry Sanaa university. 735 subjects (both males and females) and systemic free. Clinical examinations were performed including probing pocket depth, plaque index, gingival index and gingival recession. 110 Patients were less than 20 years and $9.1 \%$ healthy, $36.4 \%$ gingivitis, $22.7 \%$ generalized chronic periodontitis (GCP), $4.5 \%$ localized aggressive periodontitis (LAP), $27.3 \%$ generalized gingivitis with localized chronic periodontitis (LCP) and $0.0 \%$ generalized aggressive periodontitis (GAP). 625 Patients were more than 20 years and less than 29 years and $13.6 \%$ healthy, $8.7 \%$ gingivitis, $29.1 \%$ generalized chronic periodontitis (GCP), $2.7 \%$ localized aggressive periodontitis (LAP), $45.6 \%$ generalized gingivitis with localized chronic periodontitis (LCP) and $0.2 \%$ generalized aggressive periodontitis (GAP). Age, gender, education, tooth brushing habit, smoking, khat chewing and shamaa use habit were significantly $(P \leq 0.05)$ associated with periodontal status.

The study confirmed various socio-demographic risk factors/indictors associated with increased risk of periodontitis among Yemeni young dental patients.

Keywords: Khat, periodontal disease, prevalence, risk factors/indicators.

Article Info: Received 1 September 2017; Revised 4 October; Accepted 3 November, Available online 15 November 2017 Cite this article-

Al-Hajri MM, Mofudal A, Al-Shami AA, Al-Surihy L, Ali NM. Risk factors of periodontal diseases among Yemeni young dental patients. Universal Journal of Pharmaceutical Research 2017; 2(5): 60-64.

DOI: http://doi.org/10.22270/ujpr.v2i5.CS1

Address for Correspondence:

Manal M. Al-Hajri, Oral Medicine, Oral Diagnosis and Periodontology Department, Sanaa University, Yemen, E-mail: dent.manal@yahoo.com

\section{INTRODUCTION}

Periodontitis is a chronic infectious disease which results in biofilm formation on tooth and root surfaces and subsequent destruction of periodontal tissue because of an accelerated host response to pathogenic bacteria. Periodontitis is mostly promoted by microorganisms which are the primary cause for developing periodontitis ${ }^{1,14}$. Periodontitis is a multi factorial disease with the dental biofilm as an initiator but is influenced by various factors. These include subject characteristics, social and behavioral factors, systemic factors, genetic factors, tooth related factors, microbial structure of dental biofilm ${ }^{2,16}$.

Periodontal diseases can be divided into two major groups:

(a) Gingivitis-reversible gingival inflammation with no destruction of the periodontal supporting tissues. It is related to a nonspecific bacterial challenge ${ }^{3}$.

b) Periodontitis- gingival inflammation with destruction of the periodontal supporting tissues (periodontal ligament mutnemec and alveolar bone) related to some specific periodontal pathogens ${ }^{4,14}$. Chronic periodontitis is the most common type of destructive periodontal disease and shows a slowly progression pattern characterized by bursts of disease activity separated by quiescent periods of various durations ${ }^{10}$. Aggressive periodontitis encompasses, rapidly progressive forms of periodontitis, often commencing during adolescence and early adulthood, hence classified as early onset periodontitis ${ }^{5-7}$.

A risk factor can be defined as an occurrence or characteristic that has been associated with the increased rate of a subsequently occurring disease. Risk factors may be modifiable or non-modifiable. Modifiable risk factors are usually environmental or behavioral in nature whereas non-modifiable risk factors are usually intrinsic to the individual and therefore not easily changed socioeconomic status (SES) indicators (i.e., income, house hold and education), were included in the analyses of the 
previous studies which showed differences in periodontal health ${ }^{8}$. It can be clear that higher education individuals with more secure income showed better gingival health when compared with those individuals with lower educational level with insecure income?

Hormonal fluctuations in the female patient may alter the status of periodontal health. Such changes may occur during puberty, the menstrual cycle, pregnancy, or menopause. Numerous studies reported higher periodontal destruction among males compared to the female population. The reasons for these sex differences are not clear, but they are thought to be related to the ignorance of oral hygiene, which is usually observed among males ${ }^{4}$. There is accumulating evidence for a higher level of periodontal disease among smokers ${ }^{10-13}$. Tobacco smoking exerts a substantial destructive effect on the periodontal tissues and increases the rate of periodontal disease progression. Smokers with periodontal disease seem to show less signs of clinical inflammation and gingival bleeding compared to nonsmokers. That could be explained by the fact that nicotine exerts local vasoconstriction, reducing blood flow, edema, and clinical signs of inflammation ${ }^{8}$.

The khat plant (Catha edulis Forsk) is a tree of the family Celastraceae that is frequently cultivated in certain areas of East Africa and the Arabian Peninsula. The habit of khat chewing has prevailed for centuries among populations in the horn of east Africa and the Arabian peninsula including the Yemen. Fresh leaves of khat (Catha edulis Forsk) are customarily chewed to attain a state of stimulation. Alkaloids structurally related to amphetamine are contained within the leaves of the khat plant. A high proportion of the adult population in Yemen chew khat on a daily basis for the pleasing mild stimulant effect ${ }^{3}$. In Yemen $90 \%$ of adult male chewed khat three to four hours daily. The number for females might be as high as $50 \%$ or even higher as young women took up the habit. A recent study for the World Bank estimated that $73 \%$ of women in Yemen chewed the khat leaf more or less frequently. Meanwhile, a staggering 15-20\% of children under the age of 12 were also daily consumers. Women and men practiced the habit separately, while plucking the tender leaves from the branches and tucking them into the cheek, eventually forming a wad that could bulge almost to the size of a tennis ball ${ }^{5}$. There are no laws restricting its use, although the government discourages it. Traditionally, khat has been used as a socializing drug and this is still very much the case ${ }^{12}$. Reiner et al., revealed that Khat consumption may affect the periodontium particularly among younger individuals ${ }^{15}$. Still, they did not display obviously the role of different variables of Khat, primarily, the duration and frequency of chewing. AlHajri et al., ${ }^{3}$ demonstrated highly significant difference in the mean of gingival recession when comparing chewing side and non-chewing side. The difference was highly significant when the gingival recession on buccal surfaces was compared with others surfaces. $A L$-Sharabi ${ }^{6}$ showed that Khat consumption may affect the periodontal tissues. The study revealed that Khat chewing causes many lesions to the supporting structure of the teeth, namely gingivitis, periodontal pocket formation, gingival recession, tooth mobility and finally tooth mortality.

The aim of the present study is to evaluate the impact of a variety of risk indicators namely age (years), gender, education level, frequency of tooth cleaning and smoking. Shamaa use and khat chewing habits are also investigated.

\section{MATERIALS AND METHODS}

A total number of 735 subjects (both males and females). All selected subjects were healthy and free from any systemic disease that may affect the periodontium according to detailed questionnaire of dental modifications of the Cornell medical index ${ }^{11}$ Pregnant and lactating women should be excluded from the study. Clinical examinations were performed including probing pocket depth, plaque index, gingival index, clinical attachment level and gingival recession. All subjects were selected from the outpatient department of Oral Medicine, Oral Diagnosis and Periodontology, Faculty of Dentistry, Sana a university Sana a university and the study was conducted over a period of one year (Mar 2014/Mar 2015). The study protocol was approved by the Ethical Committee of the Faculty of Medicine and Health Sciences, Sana a University, Yemen. The study was explained to the patients and informed consent was obtained. Analysis results were subjected to statistical analysis. Mean values and standard deviation were calculated, and Chi-square test was used for comparison. SPSS software, version 19 manufactured by IBM, Chicago Illinois USA corporation was used to perform the statistical analysis. A statistical value of $<0.05$ was deemed to be significant.

\section{RESULTS}

The prevalence of periodontal diseases was $87.2 \%$ and of healthy was $12.8 \%$. Periodontal diseases diagnosis and distribution according age groups of study participants are shown in Table 1.

Table 1: Prevalence of periodontal diseases on study population.

\begin{tabular}{|c|c|c|c|c|c|c|c|c|c|}
\hline \multicolumn{2}{|c|}{ Particular } & \multicolumn{6}{|c|}{ Diagnosis } & \multirow[t]{2}{*}{ Total } & \multirow[t]{2}{*}{ P value } \\
\hline & & $\mathbf{H}$ & $\mathbf{G}$ & GCP & LAP & G with LCP & GAP & & \\
\hline \multirow{5}{*}{ Age } & \multirow{2}{*}{$<20$ years } & 10 & 40 & 25 & 5 & 30 & 0 & 110 & \\
\hline & & $9.1 \%$ & $36.4 \%$ & $22.7 \%$ & $4.5 \%$ & $27.3 \%$ & $0.0 \%$ & $100.0 \%$ & \\
\hline & \multirow{2}{*}{$20-29$ years } & 70 & 45 & 150 & 14 & 235 & 1 & 515 & $.000^{*}$ \\
\hline & & $13.6 \%$ & $8.7 \%$ & $29.1 \%$ & $2.7 \%$ & $45.6 \%$ & $0.2 \%$ & $100.0 \%$ & \\
\hline & Total & $\begin{array}{c}80 \\
128 \%\end{array}$ & $\begin{array}{c}85 \\
136 \%\end{array}$ & 175 & 19 & 265 & 1 & 625 & \\
\hline
\end{tabular}


Total 110 Patients were less than 20 years [9.1\% healthy $(\mathrm{H}), 36.4 \%$ gingivitis $(\mathrm{G}), 22.7 \%$ generalized chronic periodontitis (GCP), $4.5 \%$ localized aggressive periodontitis (LAP), $27.3 \%$ generalized gingivitis with localized chronic periodontitis (G with LCP) and $0.0 \%$ generalized aggressive periodontitis (GAP)]. 625 Patients were more than 20 years and less than 29 years $[13.6 \%$ healthy $(\mathrm{H}), \quad 8.7 \%$ gingivitis $(\mathrm{G}), \quad 29.1 \%$ generalized chronic periodontitis (GCP), $2.7 \%$ localized aggressive periodontitis (LAP), $45.6 \%$ generalized gingivitis with localized chronic periodontitis ( $\mathrm{G}$ with $\mathrm{LCP}$ ) and $0.2 \%$ generalized aggressive periodontitis (GAP)]. Gender, education level, tooth brushing habit, smoking, khat chewing and shamaa use habits were associated with periodontal status. Forward stepwise regression analysis showed a significant association of periodontitis with gender, tooth brushing habit, and khat chewing (Table 2). Overview on Plaque index (PI), gingival index (GI), pocket depth (PD), gingival recession and clinical attachments level (CAL) means are shown in Table 3. This Table shows that the healthy group demonstrates the lowest values of all examined parameters, whereas the AgP group shows the highest values.

Table 2: Demographic data of study population.

\begin{tabular}{|c|c|c|c|c|c|c|c|c|c|}
\hline Particular & & Healthy & $\mathbf{G}$ & GCP & LAP & $\begin{array}{l}\text { GG with } \\
\text { LCP }\end{array}$ & GAP & Total & $P$ \\
\hline \multirow{2}{*}{ Gender } & Male & $\begin{array}{c}10 \\
(3.1 \%)\end{array}$ & $\begin{array}{c}55 \\
(17.2 \%)\end{array}$ & $\begin{array}{c}95 \\
(29.7 \%)\end{array}$ & $\begin{array}{c}15 \\
(4.7 \%)\end{array}$ & $\begin{array}{c}145 \\
(45.3 \%)\end{array}$ & $\begin{array}{c}0 \\
(0.0 \%)\end{array}$ & $\begin{array}{c}320 \\
(100.0 \%)\end{array}$ & \\
\hline & Female & $\begin{array}{c}70 \\
(23.0 \%)\end{array}$ & $\begin{array}{c}30 \\
(9.8 \%)\end{array}$ & $\begin{array}{c}80 \\
(26.2 \%)\end{array}$ & $\begin{array}{c}4 \\
(1.3 \%)\end{array}$ & $\begin{array}{c}120 \\
(39.3 \%)\end{array}$ & $\begin{array}{c}1 \\
(0.3 \%)\end{array}$ & $\begin{array}{c}305 \\
(100.0 \%)\end{array}$ & \\
\hline \multirow[b]{2}{*}{ Age } & $<20$ years & $\begin{array}{c}10 \\
01 \%\end{array}$ & $\begin{array}{c}40 \\
(364 \%)\end{array}$ & $\begin{array}{c}25 \\
(227 \%)\end{array}$ & $\begin{array}{c}5 \\
45 \%\end{array}$ & $\begin{array}{c}30 \\
(273 \%)\end{array}$ & $\begin{array}{c}0 \\
(00 \%)\end{array}$ & $\begin{array}{c}110 \\
(1000 \%\end{array}$ & $.000^{*}$ \\
\hline & $\begin{array}{l}20-29 \\
\text { years }\end{array}$ & $\begin{array}{c}70 \\
(13.6 \%)\end{array}$ & $\begin{array}{c}45 \\
(8.7 \%)\end{array}$ & $\begin{array}{c}150 \\
(29.1 \%)\end{array}$ & $\begin{array}{c}14 \\
(2.7 \%)\end{array}$ & $\begin{array}{c}235 \\
(45.6 \%)\end{array}$ & $\begin{array}{c}1 \\
(0.2 \%)\end{array}$ & $\begin{array}{c}515 \\
(100.0 \%)\end{array}$ & \\
\hline \multirow{3}{*}{ Education } & Less & $\begin{array}{c}0 \\
(0.0 \%)\end{array}$ & $\begin{array}{c}40 \\
(17.8 \%)\end{array}$ & $\begin{array}{c}72 \\
(32.0 \%)\end{array}$ & $\begin{array}{c}12 \\
(5.3 \%)\end{array}$ & $\begin{array}{c}100 \\
(44.4 \%)\end{array}$ & $\begin{array}{c}1 \\
(0.4 \%)\end{array}$ & $\begin{array}{c}225 \\
(100.0 \%)\end{array}$ & $.000 *$ \\
\hline & $\begin{array}{l}\text { High- } \\
\text { school }\end{array}$ & $\begin{array}{c}10 \\
(5.3 \%)\end{array}$ & $\begin{array}{c}30 \\
(16.0 \%)\end{array}$ & $\begin{array}{c}58 \\
(30.9 \%)\end{array}$ & $\begin{array}{c}5 \\
(2.7 \%)\end{array}$ & $\begin{array}{c}85 \\
(45.2 \%)\end{array}$ & $\begin{array}{c}0 \\
(0.0 \%)\end{array}$ & $\begin{array}{c}188 \\
(100.0 \%)\end{array}$ & \\
\hline & Higher & $\begin{array}{c}70 \\
(33.0 \%)\end{array}$ & $\begin{array}{c}15 \\
(7.1 \%)\end{array}$ & $\begin{array}{c}45 \\
(21.2 \%)\end{array}$ & $\begin{array}{c}2 \\
(0.9 \%)\end{array}$ & $\begin{array}{c}80 \\
(37.7 \%)\end{array}$ & $\begin{array}{c}0 \\
(0.0 \%)\end{array}$ & $\begin{array}{c}212 \\
(100.0 \%)\end{array}$ & \\
\hline \multirow{3}{*}{ Brushing } & Non & $\begin{array}{c}0 \\
(0.0 \%)\end{array}$ & $\begin{array}{c}37 \\
(16.8 \%)\end{array}$ & $\begin{array}{c}74 \\
(33.6 \%)\end{array}$ & $\begin{array}{c}9 \\
(4.1 \%)\end{array}$ & $\begin{array}{c}99 \\
(45.0 \%)\end{array}$ & $\begin{array}{c}1 \\
(0.5 \%)\end{array}$ & $\begin{array}{c}220 \\
(100.0 \%)\end{array}$ & $.000 *$ \\
\hline & Irregular & $\begin{array}{c}10 \\
(4.3 \%)\end{array}$ & $\begin{array}{c}38 \\
(16.4 \%)\end{array}$ & $\begin{array}{c}78 \\
(33.6 \%)\end{array}$ & $\begin{array}{c}0 \\
(0.0 \%)\end{array}$ & $\begin{array}{c}106 \\
(45.7 \%)\end{array}$ & $\begin{array}{c}0 \\
(0.0 \%)\end{array}$ & $\begin{array}{c}232 \\
(100.0 \%)\end{array}$ & \\
\hline & Regular & $\begin{array}{c}70 \\
(41.2 \%) \\
\end{array}$ & $\begin{array}{c}10 \\
(5.9 \%) \\
\end{array}$ & $\begin{array}{c}20 \\
(11.8 \%) \\
\end{array}$ & $\begin{array}{c}10 \\
(5.9 \%) \\
\end{array}$ & $\begin{array}{c}60 \\
(35.3 \%) \\
\end{array}$ & $\begin{array}{c}0 \\
(0.0 \%) \\
\end{array}$ & $\begin{array}{c}170 \\
(100.0 \%) \\
\end{array}$ & \\
\hline \multirow{2}{*}{ Smoking } & No & $\begin{array}{c}80 \\
(15.3 \%)\end{array}$ & $\begin{array}{c}67 \\
(12.8 \%)\end{array}$ & $\begin{array}{c}141 \\
(27.0 \%)\end{array}$ & $\begin{array}{c}19 \\
(3.6 \%)\end{array}$ & $\begin{array}{c}215 \\
(41.1 \%)\end{array}$ & $\begin{array}{c}1 \\
(0.2 \%)\end{array}$ & $\begin{array}{c}523 \\
(100.0 \%)\end{array}$ & $.000 *$ \\
\hline & Yes & $\begin{array}{c}0 \\
(0.0 \%)\end{array}$ & $\begin{array}{c}18 \\
(18.4 \%)\end{array}$ & $\begin{array}{c}30 \\
(30.6 \%)\end{array}$ & $\begin{array}{c}0 \\
(0.0 \%)\end{array}$ & $\begin{array}{c}50 \\
(51.0 \%)\end{array}$ & $\begin{array}{c}0 \\
(0.0 \%)\end{array}$ & $\begin{array}{c}98 \\
(100.0 \%)\end{array}$ & \\
\hline \multirow{2}{*}{ Khat chewing } & No & $\begin{array}{c}80 \\
(29.6 \%)\end{array}$ & $\begin{array}{c}25 \\
(9.3 \%)\end{array}$ & $\begin{array}{c}65 \\
(24.1 \%)\end{array}$ & $\begin{array}{c}5 \\
(1.9 \%)\end{array}$ & $\begin{array}{c}95 \\
(35.2 \%)\end{array}$ & $\begin{array}{c}0 \\
(0.0 \%)\end{array}$ & $\begin{array}{c}270 \\
(100.0 \%)\end{array}$ & $.000^{*}$ \\
\hline & Yes & $\begin{array}{c}0 \\
(0.0 \%)\end{array}$ & $\begin{array}{c}60 \\
(17.1 \%)\end{array}$ & $\begin{array}{c}105 \\
(30.0 \%)\end{array}$ & $\begin{array}{c}14 \\
(4.0 \%)\end{array}$ & $\begin{array}{c}170 \\
(48.6 \%)\end{array}$ & $\begin{array}{c}1 \\
(0.3 \%)\end{array}$ & $\begin{array}{c}350 \\
(100.0 \%)\end{array}$ & \\
\hline \multirow[t]{2}{*}{ Shamaa use } & No & $\begin{array}{c}80 \\
(14.9 \%)\end{array}$ & $\begin{array}{c}72 \\
(13.4 \%)\end{array}$ & $\begin{array}{c}140 \\
(26.1 \%)\end{array}$ & $\begin{array}{c}14 \\
(2.6 \%)\end{array}$ & $\begin{array}{c}229 \\
(42.7 \%)\end{array}$ & $\begin{array}{c}1 \\
(0.2 \%)\end{array}$ & $\begin{array}{c}80 \\
(14.9 \%)\end{array}$ & $.000 *$ \\
\hline & Yes & $\begin{array}{c}0 \\
(0.0 \%)\end{array}$ & $\begin{array}{c}13 \\
(16.0 \%)\end{array}$ & $\begin{array}{c}27 \\
(33.3 \%)\end{array}$ & $\begin{array}{c}5 \\
(6.2 \%)\end{array}$ & $\begin{array}{c}36 \\
(44.4 \%)\end{array}$ & $\begin{array}{c}0 \\
(0.0 \%)\end{array}$ & $\begin{array}{c}0 \\
(0.0 \%)\end{array}$ & \\
\hline
\end{tabular}

Table 3: Overview on periodontal clinical parameters.

\begin{tabular}{lccccc}
\hline Diagnosis & Plaque index & Gingival index & Pocket depth $(\mathbf{m m})$ & Recession & CAL \\
\hline H & $.00 \pm 0.000$ & $.00 \pm 0.000$ & $00 \pm 0.000$ & $.00 \pm 0.000$ & $.00 \pm 0.000$ \\
G & $1.09 \pm .395$ & $1.40 \pm .430$ & $.882 \pm 1.0537$ & $.24 \pm .752$ & $1.12 \pm 1.166$ \\
CP & $1.52 \pm .448$ & $1.27 \pm .517$ & $3.743 \pm 1.9605$ & $4.17 \pm 2.007$ & $7.91 \pm 3.302$ \\
LAP & $1.90 \pm .520$ & $1.40 \pm .289$ & $7.333 \pm .5774$ & $5.67 \pm .577$ & $8 \pm 6.928$ \\
GG with LP & $1.44 \pm .541$ & $1.25 \pm .522$ & $2.434 \pm 2.7814$ & $2.79 \pm 1.683$ & $5.23 \pm 2.530$ \\
GAP & $1.00 \pm .00$ & $1.80 \pm .241$ & $7.368 \pm 4.1157$ & $2.60 \pm 2.322$ & $9 \pm 6.9$ \\
\hline
\end{tabular}

\section{DISCUSSION}

The term risk factor refers to characteristic of personal behavior or lifestyle, an environmental exposure, or an inherited characteristic, which is known, on the basis of epidemiologic evidence, to be linked with a healthrelated condition". Risk factors are portion of the causal chain for a specific disease or can lead to host exposure to a disease ${ }^{8}$. This study reports the status of the periodontium in the general young population attending a dental hospital for a self-perceived periodontal problem or referred by a dentist. Prevalence of periodontal diseases is based on disease definition or diagnostic criteria. The prevalence of 
chronic periodontitis was $70.4 \%$ (mostly localized chronic periodontitis $42.4 \%$ ) more than expected. The prevalence of $\mathrm{AgP}$ was $3.2 \%$ within the range reported in the US African Americans (2.8\%). Deep pockets were found only in $0.29 \%$ of the study sample on Jordanian adolescents. A higher prevalence of AgP $(6.0 \%)$ were reported in Iraq as well as in Brazil $(5.5 \%)^{17}$

Most participants were 20-29 years old, probably reflecting the large proportion of young individuals that most came to periodontal clinic. The prevalence of gingivitis $(13.6 \%)$ was lower than expected, possibly because most participants less educated or because of the strict exclusion criteria. Our results demonstrated that most aggressive and chronic periodontitis patients were males, which may be attributed to poor attitude towards health and bad habits. Whereas more healthy patients were females, which may be attributed to nonchewers khat and non-smokers. Studies in the past have shown that females have a better periodontal status and a more positive dental health behavior compared to males. Moreover, most smokers in china were males and that might make clear the higher prevalence of severe periodontitis among males than females ${ }^{4}$.

Lack of oral hygiene among Yemeni shows a high prevalence of chronic periodontitis, which adds a further dimension to the consideration of periodontitis among Yemeni's young population. It proves that there is a direct relationship between oral hygiene and periodontitis. Moreover, Al-Kholani, found that the mean oral hygiene index of chewers was $(2.12 \pm 0.86)$ while that of non-chewers was $(1.54 \pm 1.12)^{2}$. Patient's education in terms of oral health and how they effectively brush their teeth and use interdental aids will definitely reduce the morphological changes that are associated with such habit. Our study clearly showed that most participants were non-smokers and non-shama user, more likely reflecting the large proportion of young individuals in the Yemeni population are non-smokers and non-shama users. Whereas most of them are khat chewers and most of chewers have generalized gingivitis with localized periodontitis $(48.6 \%)$ related to teeth of chewer side found mainly as gingival recession. This is consistent with previous findings of Alakhali, and Al-Hajri et al., ${ }^{3}$ who found that the mean values of gingival recession for chewing side more than non-chewing sides ${ }^{1}$. Healthy gingivae were observed among those who were non khat-chewers $80(29.6 \%)$. The prevalence of gingivitis was higher among those who were khatchewers 60(17.1\%) when compared to non khatchewers 25(9.3\%) with statistically significant difference.

Moreover, the prevalence of periodontitis was higher among those who were khat-chewers $82.9 \%$ compared to non khat-chewers $61.2 \%$ with p-value less than 0 , 05 . Results of this study revealed that khat is too harmful to the periodontium as $79.5 \%, 31.8 \%$ and 6.4 of chewers had gum bleeding, periodontal pockets and gum recession respectively, while $48.7 \%, 12 \%$ and $1.9 \%$ of non-chewers had gum bleeding, periodontal pockets and gum recession respectively $(\mathrm{p}<0.05)$.
The prevalence of gingivitis was higher among cigarette smokers $18.4 \%$ compared to nonsmokers $12.8 \%$. Also the prevalence of periodontitis was highest $81.6 \%$ in those who are smokers when compared to nonsmokers patients (71.9\%) with statistically significant difference with P-value also less than 0.05 .The present study observed that shamaa use seem to influence periodontal disease. The results of the present study sustain the need for further extensive screenings that could clarify the influence of individual and population risk indicators and also provide more relevant information on the prevalence of periodontitis. When education levels were compared to periodontal status, our study showed a positive association between higher education levels and better periodontal status ${ }^{8}$.

\section{CONCLUSION}

The study confirmed various socio-demographic risk factors/indictors associated with increased risk of periodontitis among Yemeni young dental patients.

\section{ACKNOWLEDGEMENTS}

Authors are thankful for Dr. Adnan Al-Makhathy for his kind help with statistical analysis.

\section{AUTHOR'S CONTRIBUTION}

The manuscript was carried out, written, and approved in collaboration with all authors.

\section{CONFLICT OF INTEREST}

No conflict of interest associated with this work.

\section{REFERNCES}

1. Alakhali M. Tooth lost and gingival recession as a risk factor of khat chewing in Yemen. Cairo Dental J 2008; 2: 171- 176.

2. Al-Kholani A. Influence of Khat Chewing on Periodontal Tissues and Oral Hygiene Status among Yemenis. Dental Res J 2010; 7(1): 1-6. PMID: 21448439

3. Al-Hajri, M, El Refaey M, Fat.halla GE, El-Firt EY. Apoptosis due to Kaht chewing analysed by p53expression in gingival tissue. Egyption Dental J 2013; 59(3):3207:3215

4. Al-Jehani Y. Risk Factors of Periodontal Disease: Review of the Literature. Int J Dentistry 2014; 182513: 9. https://doi.org/10.1155/2014/182513

5. Al-Mugahed, L. Khat chewing in Yemen: turning over a new leaf. Bulletin of the World Health Organization. 2008; 86(10): 741-742. https://doi.org/10.2471/BLT.08.011008

6. AL-Sharabi A. Oral and para-oral lesions caused by takhazeenalqat (chewing). 2002; PhD. Khartoum University.https://doi.org/10.1111/odi.12188

7. American Academy of Periodontology. Task Force Report on the Update to the 1999 Classification of Periodontal Diseases and Conditions. J Periodontol 2015; 86(7):835838.https://doi.org/10.1902/jop.2015.157001

8. P Avasthy, V Govila, S Verma, VA Pant, M Sharma M. Risk factors for periodontal diseases. J App Dental Med Sci 2015; (1): 1.https://doi.org/10.1155/2014/182513

9. Bokhari SA, Suhail AM, Malik AR, Imran MF Periodontal disease status and associated risk factors in patients attending a Dental Teaching Hospital in Rawalpindi, Pakistan. J Indian Soc of Period 2015; 19(6):678-682. https://doi.org/10.4103/0972-124X.156882

10. Dayse RDZ, Meuse, Juliana C, Ramacciato, Rogério HL, Motta, Rui B, Brito Júnior and Flávia M. Impact of the 
severity of chronic periodontal disease on quality of life. J Oral Sci. 2015; 57(2):87-94.

https://doi.org/10.2334/josnusd.57.87

11. Kerr DA and Millard HD. Oral Diagnosis, St. Louis: C. B. Mosby Co; 70. 1965.

12. Kirby A. (2017). [online] Available at: http://news.bbc.co.uk/2/hi/programmes/6530453.stm, 2007 [Accessed 4 Mar. 2017].

13. Kubota M, Tanno-Nakanishi M, Yamada S, Okuda K, Ishihara K. Effect of smoking on subgingival microflora of patients with periodontitis in Japan. BMC Oral Health. 2011; 11(1). https://doi.org/10.1186/1472-6831-11-1

14. Igari1 $\mathrm{K}$, Kudo1 $\mathrm{T}$, Toyofuku $\mathrm{T}$, InoueY and Iwai $\mathrm{T}$. Association between periodontitis and the development of systemic diseases. Oral Biol Dent 2014; ID 874528. https://doi.org/10.1371/journal.pone.0225247
15. Reiner M, Mathias E, Thomas S, Lavin FJ. Periodontal status of a subject sample of Yemen. J Clin Periodontol 1996; 23: 437-443. https://doi.org/10.1111/j.1600051x.1996.tb00571.x

16. Serino G, Wadaa, M, Bougasa K. Knowledge about risk factors associated with periodontal disease among patients referred to a specialist periodontal clinic. J Oral Science Rehab 2016; 2(2):58-63.

17. Susin C, Oppermann R, Haugejorden O and Albandar J. Tooth loss and associated risk indicators in an adult urban population from south Brazil. Acta Odontologica Scand 2005; 63(2):85-93

https://doi.org/10.1080/00016350510019694

18. Zini A, Sgan-Cohen H, Marcenes W. Socio-economic position, smoking, and plaque: a pathway to severe chronic periodontitis. J Clin Period 2010; 38(3), 229. https://doi.org/10.1111/j.1600-051X.2010.01689.x 